\title{
JOURNAL OF PHILOSOPHICAL STUDIES
}




\section{JOURNAL OF \\ PHILOSOPHICAL \\ STUDIES}

EDITED BY

SYDNEY E. HOOPER

WITH THE ASSISTANCE OF

\begin{tabular}{lll} 
WILLIAM BROWN & JULIAN S. HUXLEY & J. H. MUIRHEAD \\
M. GINSBERG & F. B. JEVONS & BERTRAND RUSSELL \\
G. DAWES HICKS & HAROLD J. LASKI & G. F. STOUT \\
L. T. HOBHOUSE & A. D. LINDSAY & A. E. TAYLOR \\
\multicolumn{1}{c}{ J. ARTHUR THOMSON } & CLEMENT C. J. WEBB
\end{tabular}

VOL. II. - I 927

LONDON :

MACMILLAN \& CO., LIMITED,

ST. MARTIN'S STREET, W.C. 2

1927 
PRINTED IN GREAT BRITAIN BY UNWIN BROTHERS, LIMITED LONDON AND WOKING 


\section{CONTENTS OF VOLUME II}

\section{ARTICLES.}

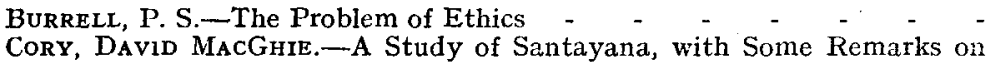

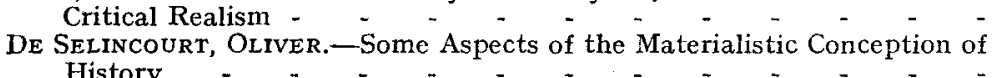
History

EDITOR, The.-Freedom

Gregory, Joshua C.-The Animate and Mechanical Models of Reality -

HoERnzt, R. F. Alfred.-Prolegomena to the Study of the Black Man's Mind -

HuXIEY, Julian S.-Mind Considered from the Point of View of Biology -

Joachim, Harold H.-The Attempt to Conceive the Absolute as a Spiritual Life

Kaye, Michae - - The Possibility of Man's Freedom -

LAIRD, JoHN.--Social Philosophy of Smith's "Wealth of Nations" -

CODGE, SIR OLIVER.-Life and Matter - - - - - - -

Lossky, N.-Limits of Evolution - - - - - - - - -

Mackenzie, J. S.-Present Tendencies of Speculative Philosophy - - 449

Macmurray, John.-Government by the People - - - - $\quad$ - $\quad$ - 532

REYBURN, Hugh A.-A Functional Theory of Knowledge-I - - - - 3I5

." ", A Functional Theory of Knowledge-II - - - 463

Rot", LeON."-The Goodness of God - - - - - _ _ - $\quad$ - 503

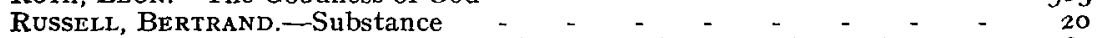

Smrth, G. ElLiot.-The Philosophical Background of Ethnological Theory - $\quad$ I 82

Stapledon, Olaf. - The Bearing of Ethics on Psychology - - - - 365

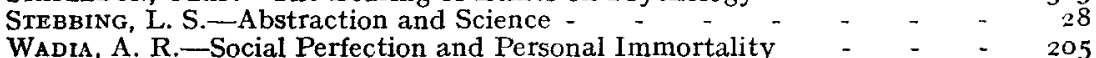

Wadi, A. R.-Social Perfection and Personal Immortality
WebB, Clement C. J.-God and the World - - -

Wolf, A.-Spinoza - - - - - - - -

Wrinch, Dorothy.-The Relations of Science and Philosophy - - - $\quad$ - 53

\section{PHILOSOPHICAL AND PSYCHOLOGICAL SURVEYS.}

Philosophy in France.-Stanley Keeling - - $\quad$ - $\quad$ - $\quad$ - $\quad$ - $\quad$ - 77

Ptanley Keeling - $\quad-\quad-\quad-\quad-\quad-\quad-377$

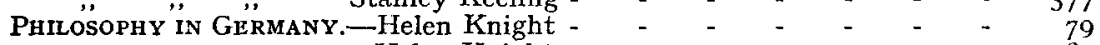

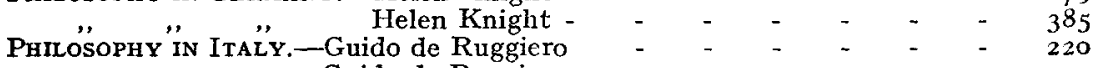

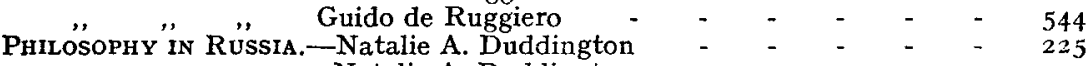

Pry" "̈ Natalie A. Duddington - - - - - 550

Psychological SuRVeY.-Beatrice Edgell - - - _ - - - 229 


\section{NEW BOOKS.}

Alverdes, Fr.-Social Life in the Animal World (J. S. Huxley) -

BAKER, JohN R.-Sex in Man and Animals (J. Arthur Thomson)

BALFour, EARL OF.-Familiar Beliefs and Transcendent Reason (A. E. Taylor)

Balliol, Master of (Edited by).-Christianity and the Present Moral Unrest (J. S. M.)

BARKER, ERNEST.-National Character and Factors in its Formation (J. S. Mackenzie) -

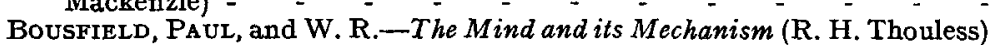

BRAHAM, ERNEST G.-Personality and Immortality in Post-Kantian Thought (E. S. Waterhouse)

Broad, C. D. -The Philosophy of Francis Bacon (Stanley V. Keeling) - -

Brown, William.-Mind and Personality (F. Aveling) - - - -

California, University of. Publications in Philosophy.-The Nature

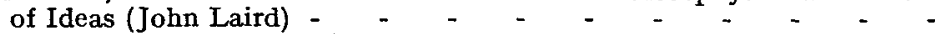

CARR, HERBE RT WILDON.-Changing Backgrounds in Religion and Ethics : $A$ Metaphysical Meditation (W. G. De Burgh) - - - - - -

Catlin, G. E. G.-The Science and Method of Politics (K. Smellie) - -

Cunynghame, Sir H.-Short Talks upon Philosophy (Norman Kemp Smith)

Defries, Amelia.-The Interpreter Geddes: The Man and his Gospel (J. S. M.)

De Ruggiero, Guido.--Sommario di Storia della Filosofia (T. E. Jessop)

DE Wulf, MaUrice.-History of Mediceval Philosophy (L. J. W.) -

DURANT, WiLL. - The Story of Philosophy (L. S. S.) - - - -

FIFE, WARner.-An Adventure in Moral Philosophy (L. S. S.) - -

HaRgreaves, H. L.-The "Faculty" of Imagination: an Enquiry Concerning the Existence of a General " Faculty," or Group Factor of Imagination (Eliot D. Hutchinson) -

HeAD, HenRY.-A A phasia and Kindred Disorders of Speech (John Laird)

HoBson. J. A.-Free-Thought in the Social Sciences (A. D. Lindsay) - -

Hocking, W. E.-Man and the State (C. Delisle Burns)

INGE, WILlIAM RALPH.-England (J. S. Mackenzie)

JORDAN, E.-Forms of Individuality (J. E. Turner) - - - - - -

KIRK, Kennetr E.-Conscience and its Problems: An Introduction to

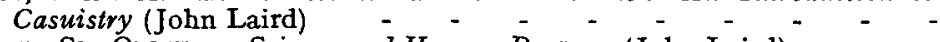

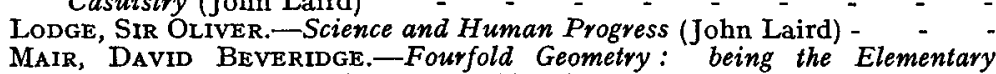
Geometry of the Four-Dimensional World (T. P. Nunn)

Masson-OURsel, Paul.-Comparative Philosophy (L. S. S.)

$-\quad-$

Morgan, C. Lloyd,-Life, Mind and Spirit (T. P. Nunn) - - - -

MURPhy, JoHN.-Primitive Man, His Essential Quest (N. F. Hall) - -
Noble, EDMUND.-Purposive Evolution: The Link between Science and Religion (C. Lloyd Morgan) -

OAKDEN, E. C.-See StuRT.

PERRY, Ralph Barton.-General Theory of Value: Its Meaning and Basic Principles Construed in Terms of Interest (John Laird) -

PerRy, Ralph Barton.-Philosophy of the Recent Past (L. S. S.) - -

RaDHakrishnaN, S.-The Hindu View of Life (J. S. Mackenzie) - - -

RANDALI, JoHn H., JR.-The Making of the Modern Mind (John Laird)

Rrvers, W. H. R.-Psychology and Ethnology (W. J. Perry) - - -

ROTH, LEON (Edited by).-Correspondence of Descartes and Constantyn Huygens, I635-1647 (Edwin A. Burtt) -

Sellars, Roy Wood.-The Principles and Problems of Philosophy (Helen Knight)

SMart, HaRold R.-The Philosophical Presuppositions of Mathematical Logic (R. B. Braithwaite)

Smuts, Rt. HoN. J. C.-Holism and Evolution (C. Lloyd Morgan) - -

Snow, A. J.-Matter and Gravity in Newton's Physical Philosophy (L. J. Russell)

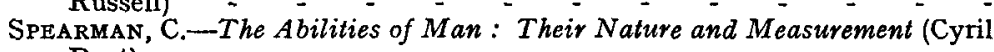

Burt) -
Stoops, JoHN Dashxell.-Ideals of Conduct: Attitudes (L. S. S.)

vi 


\section{O N T E N T S}

Street, Charles LARRABer.-Individualism and Individuality in the Philosophy of John Stuart Mill (O. De Selincourt) - - - -

Streeter, Burnett Hillman.-Reality: $A$ New Correlation of Science and Religion (A. E. Elder)

Sturt, Mary, and OAKDEN, E. C.-Modern Psychology and Ëücation-a Text-Book of Psychology for Students in Training Colleges and Adult Evening Classes (R. H. Thouless) - - - $-{ }_{-}-{ }_{-}-I_{-}$

TAYLoR, A. E.-Plato : the Man and his Work (W. D. Ross) - $\quad$ - $\quad 239$

TURNER, J. E.-The Nature of Deity : a Sequel to " Personality and Reality" (W. G. De Burgh)

VoN UexkULL, J.-Theoretical Biology. Translated by D. L. Mackinnón (J. Arthur Thomson) -

Ward, James. - Psychology Applied to Education (James Drever) - We"B, Clement C. J.-Kant's Philosophy of Religion (E. S. Waterhouse) -

Whitehead, A. N.-Religion in the Making (L. Susan Stebbing)

Wirson, GeORGE A.-The Self and its World (A. K. White)

Wolf, A. - The Oldest Biography of Spinoza (edited, translated, etc.) (Harold H. Joachim)-

Wood BURNE, A. S. $-\bar{H}$ Hman Nature and Education (P. B. Ballard) - -

PAGE

579

246

396

392

413

411

553

102

234

251

403

580

\section{PERIODICALS.}

British Journal of Psychology (Vol. xvii, Part 2, October, 1926) - - - $\quad$ I2I

". " $\quad$ (Vol. xvii, Part 3, January, 1927) - $\quad$ - $\quad 268$

(Vol, xvii, Part 4, April, I927) - - - 427

International Journal of Ethics (Vol. xxxvii, No. I, October, 1926) - - 122 " " " " (Vol. xxxvii, No. 2, January, 1927) - $\quad 273$

(Vol. xxxvii, No. 3, April, 1927) - - $\quad-\quad 429$

$\begin{array}{lll}\text { Journal de Psychologie ("'Twenty-third Year, No. 9, November, 1926) - } & \text { - } & 590 \\ \text { I27 }\end{array}$

" . " " (Twenty-third Year, No. 10, December, 1926) - - 278

$\begin{array}{lll}\text { (Twenty-third Year, No. Io, December, 1926) - } & - & 278 \\ \text { (Twenty-fourth Year, No. I, January, 1927) - } & - & 278\end{array}$

(Twenty-fourth Year, No. 2, February, 1927) - $\quad$ - 437

(Twenty-fourth Year, No. 2, March, 1927) - - 438

$\begin{array}{llll}\text { Journal of Philosophy (Vol. xxiii, No. 24, November 25, 1926) - } & - & - & 593 \\ \text { (Twenty-fourth Year, No. 7, July, I927) - } & - & \text { I24 }\end{array}$

(Vol. xxiv, No. 1, January 6, 1927) - - - $\quad-\quad 275$

(Vol. xxiv, No. 6, March 17,1927) - - - - 433

(Vol. xxiv, No. 8, April 14,1927) - - - - $\quad 434$

(Vol. xxiv, No. 15, July 21, 1927) - - - $\quad-\quad 591$

Mind (Völ. xxxv, No. 140, October, 1926) - - - - - - - $\quad-\quad 592$

" (Vol. xxxvi, No. I41, January, 1927) - - $\quad-\quad-\quad-\quad-\quad-\quad 267$

,. (Vol. xxxvi, No. 142, April, 1927) - $\quad-\quad-\quad-\quad-\quad-\quad-\quad 425$

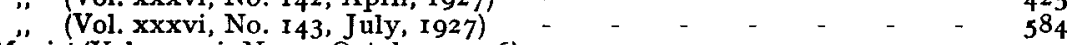

Monist (Vol. xxxvi, No. 3, October, I926) - - - - - - - - - II9

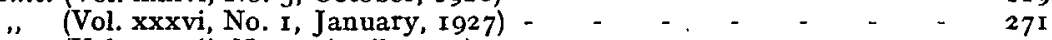

" (Vol, xxxvii, No. 2, April, 1927) - - - $\quad$ - $\quad$ - $\quad$ - $\quad$ - 431

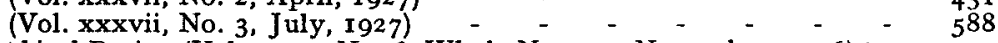

Philosophical Review (Vol. xxxv, No. 6, Whole No. 2 Io, November, 1926) - 125

" $\quad$ " (Vol. xxxvi, No. I, Whole No. 21 I, January, I927) - 270

" $\quad$ ", (Vol. xxxvi, No. 2, Whole No. 212, March, 1927) - 435

Revue $\ddot{d e}$ Métaphysique et de Morale. (Thirty-fourth Year, No. I, JanuaryMarch, 1927)

Revue Né-Scholastique de Philosophie (Twenty-eighth Year, Second Series,

No. 12, November, 1926)

Revue Philosophique (Fifty-first Year, Nos. I I and 12, Nove'mber-December,

I926)
(Fifty-second Year, Nos. I and 2 , January-February, 1927) - $\quad$ - $\quad$ - $\quad$ - $\quad$ - $\quad$ - $\quad$ - 277 
CONTENTS

CORRESPONDENCE.

BrightMaN, EDGar SIIEFFIELD -

Cook, Stanley A.

De Wulf, Maurice.

SMART, HAROLD R.

StebBING, SUSAN

Walker, Lestie J.

WOLF, A.

\section{INSTITUTE NOTES.}

Annual Meeting (1927), Addresses by (I) Professor L. T. Hobhouse, and (2) The Right Hon. the Earl of Balfour

Evening Meetings, Programme for $1927-28$

Letter of Appeal for Co-operation of Members, Programme of Lectures

Liverpool Centre

Northumberland and Durham Centre, Preliminary Announcement of Lectures

Provincial Centres, Course of Lectures, etc.

Seminar in Psychology, Proposed 


\section{CONTEN'TS}

J. SPINOZA : PROFESSOR A. WOLF . . . . PAGE

II. SUBSTANCE : Bertrand Russelt, F.R.S. . . . . . . 20

III. ABSTRACTION AND SCIENCE: L. S. StebBing, M.A. • . . 28

IV. SOCIAL PHILOSOPHY OF SMITH'S "WEALTH OF NATIONS ":

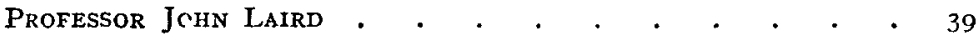

V. PROLEGOMENA TO THE STUDY OF THE BLACK MAN'S

MIND : Professor R. F. Alfred Hokrnle . . . . . 52

VI. THE PROBLEM OF ETHICS : Professor P. S. Burrell • $\quad 62$

VII. PHILOSOPHICAL SURVEY:

PHILOSOPHY IN FRANCE • • • • • • • • • 77

PHILOSOPHY IN GERMANY . . . . . . . . 79

VIII. NEW BOOKS .

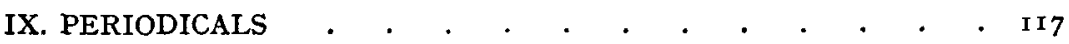

X. INSTITUTE NOTES . . . . . , , . . . . $\mathbf{I}_{3^{\circ}}$ 
PRINTED IN GREAT BTITAI:

BY UNKIN BROTHERS, LIMITED

LONDON AND WOKING 


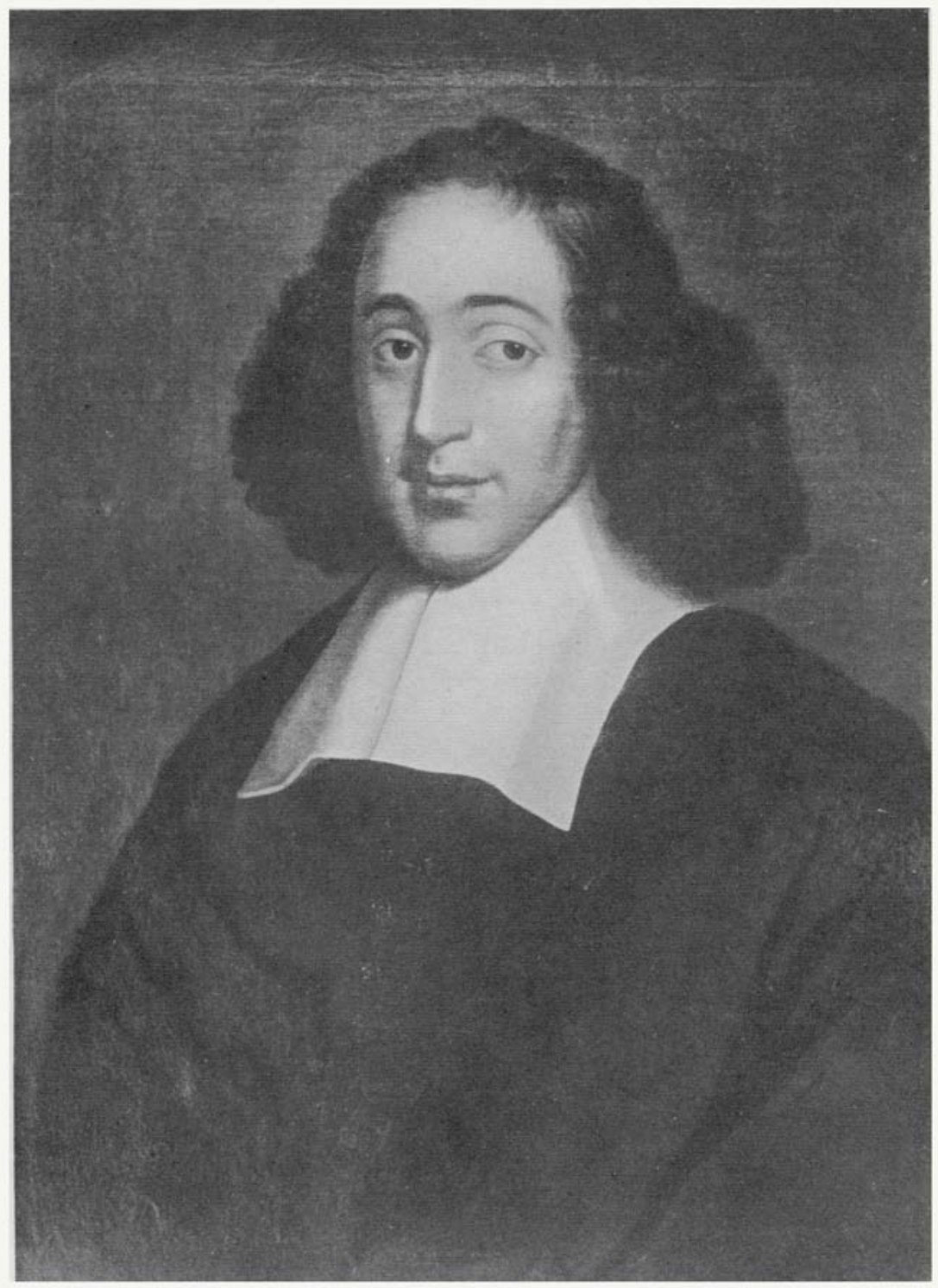

SPINOZA

I632-I677 